\title{
A comparative study of state and private university websites in Maharashtra.
}

\author{
Dr. Shobha. A. Menon, Mrs. Rimi Moitra
}

\begin{abstract}
Globalization has had a tremendous impact on every aspect of human life including higher education. In the Indian context education is partially provided by the public sector that is basically funded by the government and partially opened out to the private sector. In recent years there has been a steady growth of the private players in the education market. Most educational institutions now recognize that they need to market themselves in a climate of global competition. E-marketing is a critical component of commerce today and has penetrated deep into every field, from the marketing of tangible goods to the marketing of intangible services like education. One of the most important tools of internet marketing is the creation of a website. This paper makes a comparison of the websites of state universities and private universities. The most and least common features are noted and the percentage to which each feature is present is also noted. Results indicated that private universities have more interactive websites hence they seem to be using websites more effectively for marketing. Recommendations are made about the nature of changes needed in the websites of state universities so that they can function as tools for marketing.
\end{abstract}

\section{Introduction}

Globalization, the emerging reality of the 21 st century has had a tremendous impact on every aspect of human life including higher education. Higher education institutions are undergoing a transformation in order to cope with this changing environment. Education is one of the services covered under GATT resulting in trade in education and hence the need for marketing of education and educational institutions. In the Indian context education is partially provided by the public sector that is basically funded by the government and partially opened out to the private sector. In recent years there has been a steady growth of the private players in the education market. Private universities and educational institutions see themselves as businesses and their potential students as customers.

Traditionally, academicians and educationists however have been averse to marketing because of its link with commercialism and selling seeing it as a rejection of the traditional attitude of the nobility of education. However most educational institutions now recognize that they need to market themselves in a climate of global competition.Hence there is a transfer of the practices and concepts of marketing from other sectors to higher education. So most educational institutes now recognize the need to market them in a competitive environment and cater to the needs of their customers. In the context of educational institutions this means that the institution actively communicates and promotes its purpose, value and products to the pupils, parents, staff and wider community.

Marketers today rely heavily on the internet and the World Wide Web created to entice prospective customers. E-marketing is a critical component of commerce today and has penetrated deep into every field, from the marketing of tangible goods to the marketing of intangible services like education. One of the most important tools of internet marketing is the creation of a website. A company's website is a key tool for communicating and attracting customers and provides an interface provided to internet users for searching information or buying product/services.

Websites of educational institute have been studied by the researchers from various perspectives. Bauer and Scharl (2000) evaluated commercial, educational and nonprofit organization websites and stated that content, interactivity and navigation should be the main features of these web pages .According to Mcgullis and Toms(2001)satisfaction, ease and clarity are the most important features of university websites. Muyelle etal (2004) added one more feature to university websites namely multiple language option. Zhang and Dran (2004) developed a theoretical framework for evaluating quality of educational websites. Singh and Sook (2002) attempted to find solutions to user problems in educational websites. However Elangovan (2013) studied Bschool websites and concluded that most of the B-school websites are static. The strategic use of websites is not being done. 
Universities need to perceive their websites as one of most important tools for communication between the university and students. Universities and educational institutions especially those that receive government aid are yet to wake up to the need for marketing and the effective use of websites for marketing. They must therefore design their websites to enable a more interactive channel of communication. State universities have a social role to give their potential students good information. They must act effectively to inform students.

This paper makes a comparative analysis of university websites in order to understand the prevalence of various website features among private and state universities in the state of Maharashtra.

\section{Method}

The study covered websites of 15 universities in the state of Maharashtra including both the state $(\mathrm{N}=12)$ as well as private universities $(\mathrm{N}=03)$. This difference in number of universities covered arose because the study did not include those universities which offer only specialized programs like fisheries or technology and included only those offering general programs in the faculties of arts, science and commerce. The researcher browsed through the websites of a number of universities in great detail and also studied previous research in the field to prepare a checklist of 30 website features. Then the researcher studied each of these 16 websites and checked for the existence of a particular feature.

\section{Results}

The percentage of universities having a given feature was calculated. The features were then divided into four broad categories namely, those features present in only zero to twenty five percent of the websites, features present in twenty six to fifty percent of the websites, features present in fifty one to seventy five percent of the websites and features present in seventy six to hundred percent of the websites. This was done for both private as well as state universities.

The comparative results (Table 1) shows that among the state funded universities almost all of the websites ( $76 \%$ to $100 \%$ ) had features relating to history, contact details, courses, photo gallery, board, ordinances office details, circulars, examinations and results, notifications, events and programs and faculty details. While amongst the private universities in addition to the above features the website also show features like research activities, grants, awards, infrastructure, sitemap, accreditation information and link to library sources.

A fewer number of state university websites (51\% to $75 \%$ ) have features like campus of distance learning, academic calendar, awards, sitemap, accreditation information, link to library resources, independent URL. While the features which fall in this range amongst the private university are international relations, academic calendar, student exchange program, faculty details and link to social networking sites.

Lesser number of state university websites (26\%to50\%) has features like virtual lectures, research activities, awards, alumni details, infrastructure, feedback system, press releases and university press. While in private university the features of this range are virtual lectures, Ordinances \& circulars, alumni details, feedback system and press releases. Very few state university websites(less or equal to $25 \%$ ) had features like International relations, Research grants, student exchange program, FAQ and Link to social networking sites .Amongst the private universities the features are University press and FAQs.

Thus the results indicate that some of the features are common across websites however some are found only in a few websites. These results are discussed in the next section of the paper and recommendations for improvement are made.

\section{Discussion}

The results of the study are similar to those of previous research (Elangovan, 2013). Thus the results show a wide variance in the features paid emphasis by the state universities and private universities in Maharashtra. Majority of the state university websites have features like History, Contact details, courses, Boards, Ordinances, Office details, Examination \& Results, notifications, Photo gallery, Events \& Programs and Faculty Details. This indicates that majority of the state university websites are providing static information. The website becomes only a board where basic information is provided. The website functions more like a bill board with extremely low emphasis on interactive features. It would not be incorrect to say that this seems to defeat the very purpose of having a website. From the view point of e-marketing the website must give customers all the information they need and provide avenues to solve their queries. These aspects whereas is reflected in the websites of Private Universities. They in addition to the basic information are also emphasizing on features like Research activities, Grants, Awards, Sitemap, Accreditation Information, Infrastructure and Link to library source. Thus its highlighted from the websites of these private universities that they have really understood the importance of website. They understand that students are prospective customers. These customers while making a choice amongst the various universities would hunt for these interactive features rather than the basic information provided by the state universities. So the private universities in Maharashtra 
consider websites as a tool for E-marketing which the state universities are yet to tap. The results depicts that very few state university have features like Accreditation information, International relations, Infrastructure and Sitemap. But these are features which a student would be interested in. These are features which act as transparency indicators and also add value to the university. The university is regarded as a gateway to a better future by the students. It helps a university to establish brand image by making alliances with foreign universities. But these are commonly present in all the Private University. Features like link to social networking sites shows very little presence in the websites of state universities whereas given much importance in the websites of Private universities. These sites are now-a-days the best media vehicle for promotion. Our youth are much closer to these sites and rely more on them than any other media. An extremely alarming finding is the very low priorities accorded to FAQ's and virtual lectures. Absence of FAQ's poses a serious problem for all the stakeholders to clear doubts regarding various aspects. It is not always possible for these stakeholders to physically visit the university to enquire. So a university must stress into these aspects in order to market it successfully. The features like virtual lectures will also help students who are working and cannot attend lectures.

Some of the unique features of websites apart from those covered in our checklist are found in certain university websites. In Mumbai university websites there were features like search options, toll free helplines for anti-ragging which are very helpful features. In the website of North Maharashtra university there are features like links to job openings in Government and private companies. This feature gives value addition to the website.. Also the website has option of logging from there directly into personal mail boxes. It was noticed that websites of rural districts are much more interactive than those of urban areas. In fact the websites differ greatly from each other some websites are extremely good having a number of features and fully functional while others need a lot of improvement. But during the study the researcher found that there is a huge difference in the website features of the state universities and that of the private universities. In addition to the checklist features the private universities like symbiosis have features like 360 degree campus tour, video library which makes the website very lucrative to the stakeholders. University like Dr D.Y .Patil University has links to google application thus making the website more functional to the students.

This study highlights the fact that our state universities are yet to tap the website as a tool for customer relationship marketing. Though they have websites but are not fully functional. According to signaling theory (Spence, 1974) the quality of website provides a signal to the kind of service quality of an organization. A number of universities have websites of poor quality, which are not frequently updated and do not cater to their customers and this gives out a poor signal about service quality. According to Elangovan (2013),"Need for quality website for schools, universities and other educational institutions is constantly increasing as online technologies become a bigger part of the educational process as well as decision support for prospective students in selecting their place of study. The website also reflects the professional image of the university. "In this regard websites of state universities in Maharashtra fall far short of expectation. Technical expertise to build and maintain a website is readily available now everywhere yet they are underutilized. This indicates that universities are yet to realize that in today's market driven world, education also must be marketed and websites can be an effective tool for this purpose. To conclude state universities have many lessons to learn from the private universities in order to survive in the globalized era.

TOTAL NUMBER OF WEBSITES STUDIED: 12 state university and 3 private university

\begin{tabular}{|c|c|c|c|c|}
\hline Website Features & $\begin{array}{l}\text { No of state } \\
\text { university websites } \\
\text { with the feature }\end{array}$ & $\begin{array}{l}\% \text { of state } \\
\text { university websites } \\
\text { with the feature }\end{array}$ & $\begin{array}{l}\text { No of private } \\
\text { university websites } \\
\text { with the feature }\end{array}$ & $\begin{array}{l}\% \text { of private } \\
\text { university websites } \\
\text { with the feature }\end{array}$ \\
\hline History & 12 & 100 & 3 & 100 \\
\hline Contact details & 12 & 100 & 3 & 100 \\
\hline Campus of distance learning & 8 & 66.6 & 3 & 100 \\
\hline Courses & 12 & 100 & 3 & 100 \\
\hline Virtual Lectures & 4 & 33.3 & 1 & 33.3 \\
\hline Board & 12 & 100 & 3 & 100 \\
\hline International Relations & 3 & 25 & 2 & 66.6 \\
\hline Academic Calendar & 7 & 58 & 2 & 66.6 \\
\hline Research Activities & 4 & 33.3 & 3 & 100 \\
\hline Research Grants & 2 & 16.6 & 3 & 100 \\
\hline Ordinances and circulars & 12 & 100 & 1 & 33.3 \\
\hline Awards & 6 & 50 & 3 & 100 \\
\hline Alumni Details & 5 & 41.6 & 1 & 33.3 \\
\hline Office Details & 10 & 83.3 & 1 & 33.3 \\
\hline
\end{tabular}


A comparative study of state and private university websites

\begin{tabular}{|l|l|l|l|l|}
\hline Infrastructure & 5 & 41.6 & 3 & 100 \\
\hline Site Map & 7 & 58.3 & 3 & 100 \\
\hline Accreditation Information & 8 & 66.6 & 3 & 100 \\
\hline University Press & 4 & 33.3 & 0 & 0 \\
\hline Link to Library resources & 9 & 75 & 3 & 100 \\
\hline Feedback System & 5 & 41.6 & 1 & 33.3 \\
\hline Examinations and Results & 12 & 100 & 3 & 100 \\
\hline Notifications & 12 & 100 & 3 & 100 \\
\hline Student Exchange Program & 1 & 8.3 & 3 & 66.6 \\
\hline Photo gallery & 12 & 100 & 3 & 100 \\
\hline Independent URL & 8 & 66.6 & 0 & 100 \\
\hline FAQ & 3 & 25 & 3 & 0 \\
\hline Events and programs & 12 & 100 & 1 & 100 \\
\hline Press Releases & 6 & 50 & 2 & 33.3 \\
\hline Faculty Details & 10 & 25.3 & 66.6 \\
\hline $\begin{array}{l}\text { Link to Social Networking } \\
\text { sites }\end{array}$ & 3 & & 66.6 \\
\hline
\end{tabular}

\section{References}

[1]. Bauer and Scharl (2000)Bauer, C. Scharl,:(1999) "A Classification Framework and Assessment Model for Automated Website Evaluation." Proceedings of the Seventh European Conference on Information Systems. pp 758-65.

[2]. Elangovan, N. L (2013) Evaluating Perceived Quality of B-School Websites, Journal of Business and Management ,12(1),92-102.

[3]. McGillis, L, Toms, E.G (2001) Usability of the academic library website: Implications for design college \& Research Libraries: July, 355-367.

[4]. Muylle, S, Moenaert, R., Despontin, M. (2004) - The conceptualization and empirical validation of website user satisfaction. Information \& Management, 41(5), 543-560

[5]. Singh, I, Sook, A.( 2002) - An evaluation of the usability of South African university websites. In: Proceedings of the 2002 CITTE Conference, Durban, South Africa

[6]. Spence, A.M. (1974)-Market Signaling: Information Transfer in Hiring and Related Screening Processes. Harvard University Press, Cambridge.

[7]. Zang, Ps., Dran. G, (2001) Expectations \& ranking of website quality features: results of two studies on user perception. In proceedings of the $34^{\text {th }}$ Hawaii International Conference on System Science. 